\title{
Indole Alkaloid and other Constituents from Ocotea minarum
}

\author{
Walmir S. Garcez", Fernanda R. Garcez, Lillian May G. E. da Silva and Angela A. Shimabukuro \\ Departamento de Química, Universidade Federal de Mato Grosso do Sul, 79070-900 Campo Grande-MS, Brazil
}

\begin{abstract}
Dos frutos de Ocotea minarum foram isolados um novo alcalóide indólico, triptofol-5-O- $\beta$-Dglicopiranosídeo, a cumarina escopoletina e os flavonóides taxifolina, quercetina-7-O- $\beta$-Dglicopiranosídeo, eriodictiol-3'-O- $\beta$-D-glicopiranosídeo e naringenina-7-O- $\beta$-D-glicopiranosídeo. Do cerne foi isolado um novo alquil fenol, 3-(1,4-diidroxipentil)-5-metoxifenol, além de 5propilresorcinol, trans-asarona, lioniresinol, 3-O- $\beta$-D-glicopiranosil estigmasterol e estigmasta4,22-dien-3-ona. Da casca do caule foram obtidos o sesquiterpeno ácido lanceólico (como seu derivado éster metílico após metilação com diazometano) e $\beta$-sitosterol. O ácido lanceólico e 5propilresorcinol estão sendo relatados pela primeira vez como produtos naturais.
\end{abstract}

From the fruits of Ocotea minarum a new indole alkaloid, tryptophol-5-O- $\beta$-D-glucopyranoside, was isolated in addition to the coumarin scopoletin and the flavonoids taxifolin, quercetin-7-O- $\beta$-Dglucopyranoside, eriodictyol-3'-O- $\beta$-D-glucopyranoside and naringenin-7-O- $\beta$-D-glucopyranoside. A new alkyl phenol, 3-(1,4-dihydroxypentyl)-5-methoxyphenol, was obtained from the heartwood in addition to 5-propylresorcinol, trans-asarone, lyonyresinol, 3-O- $\beta$-D-glucopyranosyl stigmasterol and stigmasta-4,22-dien-3-one, whereas from the trunk bark the sesquiterpene lanceolic acid (as its methyl ester derivative after methylation procedures) and $\beta$-sitosterol were isolated. 5-propylresorcinol and lanceolic acid are reported for the first time as natural products.

Keywords: Ocotea minarum, Lauraceae, indole alkaloid, lanceolic acid, alkyl-phenols

\section{Introduction}

In continuation of our program on chemical investigation of Lauraceous plants occurring in the "Pantanal" and "Cerrado" of Mato Grosso do Sul, Brazil, the fruits, heartwood and trunk bark components of Ocotea minarum (Meissn.) Mez., an endemic plant which has been found up to now only in the "Cerrado", have been examined.

A previous work on the leaves of a specimen identified as $O$. minarum which was collected in Minas Gerais, Brazil, resulted in the isolation of fourteen aporphinic alkaloids. ${ }^{1}$ However, no alkaloids have been detected in the leaves of the specimen investigated in the present work. The great morphological resemblance among the species belonging to the Lauraceae is well known and sometimes this may lead to misidentification of the specimen under investigation.

We describe herein the isolation of an indole alkaloid (1), a coumarin (2) and four flavonoids $(\mathbf{3}-\mathbf{6})$ from the fruits, a lignan (7), two alkyl phenols $(\mathbf{8}, \mathbf{9})$, a aryl propene derivative $(\mathbf{1 0})$ and two steroids $(\mathbf{1 1}, \mathbf{1 2})$ from the

* e-mail: wgarcez@nin.ufms.br heartwood and a sesquiterpene (13) and a steroid (14) from the trunk bark of a specimen of Ocotea minarum collected in Campo Grande, MS State.

\section{Results and Discussion}

After a series of partition procedures and a combination of column chromatography on silica gel, gel filtration and reversed phase HPLC separations of the ethanol extract from the fruits, the indole alkaloid tryptophol-5-O- $\beta$-Dglucopyranoside (1) was isolated, together with the coumarin scopoletin (2) and the flavonoids taxifolin (3), quercetin-7-O- $\beta$-D-glucopyranoside (4), eriodictyol-3'-O$\beta$-D-glucopyranoside (5) and prunin (naringenin-7-O- $\beta$ D-glucopyranoside, $\mathbf{6}$ ).

The positive ESI-mass spectrum of $\mathbf{1}$ showed a quasimolecular ion at $\mathrm{m} / z 362(\mathrm{M}+\mathrm{Na})^{+}$accordingly to a molecular formula $\mathrm{C}_{16} \mathrm{H}_{21} \mathrm{NO}_{7}$. Its ${ }^{1} \mathrm{H}$ NMR spectrum displayed signals attributable to a 1,2,4-trisubstituted aromatic ring $(\delta 7.21, \mathrm{~d}, J 2.0 \mathrm{~Hz} ; \delta 6.85$, dd, $J 8.0$ and 2.0 $\mathrm{Hz} ; \delta 7.12, \mathrm{~d}, J 8.0 \mathrm{~Hz})$ in addition to a broad singlet at $\delta$ $6.96(1 \mathrm{H})$ (Table 1). In the region of aliphatic hydrogens, a pair of triplets at $\delta 2.82(2 \mathrm{H}, J 7.2 \mathrm{~Hz})$ and $3.80(2 \mathrm{H}, J 7.2$ 
$\mathrm{Hz})$ and signals ascribed to a sugar moiety $(\delta 4.85-3.20)$ were observed. The sugar moiety was assigned as $\beta$-Dglucopyranose on the basis of ${ }^{1} \mathrm{H}$ and ${ }^{13} \mathrm{C}$ NMR data and the $J$ value for the anomeric hydrogen at $\delta 4.85(\mathrm{~d}, J 7.5$ $\mathrm{Hz}$ ). The presence of a disubstituted indole moiety was suggested by the chemical shifts of the eight $\mathrm{sp}^{2}$ carbons in the ${ }^{13} \mathrm{C}$ NMR spectrum (Table 1). ${ }^{2}$ A downfield signal at $\delta 152.7$ indicated that the O-glucosyl residue was located para to the nitrogen atom of the indole nucleus, at the C-5 position. This assumption was also supported by the upfield signals in this spectrum attributed to C-4 and C-6 ( $\delta 106.8$ and 114.2, respectively) and the long-range HMBC correlations of H-4, H-6, H-7 and H-1' of the glucosyl moiety with C-5 (Table 1 ). The presence of a $\beta$-hydroxyethyl substituent at C-3 could be inferred by the two methylene carbon signals at $\delta 29.7$ and 62.6 which in turn showed cross-peak correlations with the two aforementioned triplets at $\delta 2.82$ and 3.80, respectively, in the HMQC spectrum. This information was corroborated by the HMBC correlations between the signals of $\mathrm{H}-10$ and that of C-2 and between the signals of $\mathrm{H}-4$ and $\mathrm{H}-10$ and that of $\mathrm{C}-3$. Therefore, compound $\mathbf{1}$ is thus unambiguously shown to be the 5-O-glucosyl derivative of tryptophol (indole-3-ethanol). Tryptophol has been isolated as a constituent of higher plants, fungi and marine organisms and is considered to be a plant auxin, ${ }^{3}$ however its 5-Oglucosyl derivative $\mathbf{1}$ was hitherto unreported in the literature.

Table 1. ${ }^{1} \mathrm{H}(300 \mathrm{MHz})$ and ${ }^{13} \mathrm{C}(75 \mathrm{MHz})$ NMR spectral data for $\mathbf{1}$ $\left(\delta, \mathrm{CD}_{3} \mathrm{OD}\right)$

\begin{tabular}{ccc}
\hline $\mathrm{C} / \mathrm{H}$ & $\delta \mathrm{H}^{\mathrm{a}}$ & $\delta \mathrm{C}$ \\
\hline & $6.96 \mathrm{~s}$ & 124.7 \\
3 & $-\overline{\mathrm{d}}(2.0)$ & 112.8 \\
4 & - & 106.8 \\
5 & $6.85 \mathrm{dd}(8.0,2.0)$ & 152.7 \\
6 & $7.12 \mathrm{~d}(8.0)$ & 114.2 \\
7 & - & 112.5 \\
8 & - & 134.5 \\
9 & $2.82 \mathrm{t}(7.2)$ & 124.2 \\
10 & $3.80 \mathrm{t}(7.2)$ & 29.7 \\
11 & $4.85 \mathrm{~d}(7.5)$ & 62.6 \\
$1^{\prime}$ & $3.47^{\mathrm{b}}$ & 104.2 \\
$2^{\prime}$ & $3.45^{\mathrm{b}}$ & 75.1 \\
$3^{\prime}$ & $3.41^{\mathrm{b}}$ & 78.1 \\
$4^{\prime}$ & $3.28^{\mathrm{b}}$ & 71.6 \\
$5^{\prime}$ & $3.49^{\mathrm{b}} 3.64^{\mathrm{b}}$ & 78.1 \\
$6^{\prime}$ & 63.7 \\
\hline
\end{tabular}

${ }^{\mathrm{a}}$ Coupling constants $(\mathrm{J}$ in $\mathrm{Hz})$ are given in parentheses; ${ }^{\mathrm{b}} \mathrm{Over}-$ lapped signals, obtained from HMQC data.

Column chromatography on silica gel of a crude ethanol extract obtained from the heartwood of Ocotea minarum followed by Sephadex LH-20 separations afforded the lignan lyonyresinol (7), the alkyl phenols 5propylresorcinol (8) and 3-(1,4-dihydroxypentyl)-5methoxyphenol (9), the aryl propene derivative transasarone (10) and the steroids 3-O- $\beta$-D-glucopyranosyl stigmasterol (11) and stigmasta-4,22-dien-3-one (12).

The ${ }^{1} \mathrm{H}$ NMR spectrum of $\mathbf{8}$ showed characteristic signals of a resorcinol derivative (two broad singlets at $\delta$ 6.28 and 6.16, the latter integrating for two hydrogens) containing an $n$-propyl group at C-5 (two triplets at $\delta 0.83$, $J 6.6 \mathrm{~Hz}$ and $2.39, J 7.5 \mathrm{~Hz}$ and one multiplet at $\delta 1.50$ ). The signal of the phenol hydrogens, which disappeared after addition of $\mathrm{D}_{2} \mathrm{O}$, was observed at $\delta$ 5.86. Accordingly, in the ${ }^{13} \mathrm{C}$ NMR spectrum of $\mathbf{8}$, four signals at $\delta 146.1$, 107.9, 156.7 and 100.2 accounted for a symmetrically substituted resorcinol ring, while resonances of two methylene and one methyl carbons at $\delta$ 32.0, 36.0 and 14.1 , respectively, were indicative of an $n$-propyl substituent at C-5. Compound $\mathbf{8}$ was thus identified as 5propylresorcinol, which has been previously detected as one of the constituents of the secretion of the ant Crematogaster deformis ${ }^{4}$ and not reported in higher plants before now.

The molecular formula of 9 was deduced as $\mathrm{C}_{12} \mathrm{H}_{18} \mathrm{O}_{4}$ on the basis of the quasi-molecular ion peak at $\mathrm{m} / \mathrm{z} 249$ $[\mathrm{M}+\mathrm{Na}]^{+}$observed in its positive ESI-mass spectrum and information provided by its ${ }^{1} \mathrm{H}$ and ${ }^{13} \mathrm{C}$ (including DEPT) NMR spectra. In the ${ }^{1} \mathrm{H}$ NMR spectrum of 9 , the presence of an 1,3,5-trisubstituted aromatic ring was inferred by the three broad singlets at $\delta 6.41,6.38$ and 6.24 (Table 2). This spectrum also showed signals attributable to one methoxyl $(\delta 3.73)$ and an aliphatic chain bearing two carbinolic hydrogens, as revealed by a triplet at $\delta 4.48(1 \mathrm{H}, J 7.1 \mathrm{~Hz})$ and a multiplet partly obscured by the OMe singlet $(\delta$ 3.73). In the HMQC spectrum, cross-peak correlations between the signals of these carbinolic hydrogens and carbon resonances at $\delta 75.2$ and 68.5 , respectively,

Table 2. ${ }^{1} \mathrm{H}(300 \mathrm{MHz})$ and ${ }^{13} \mathrm{C}(75 \mathrm{MHz})$ NMR spectral data for 9 $\left(\delta, \mathrm{CDCl}_{3}\right)$

\begin{tabular}{ccc}
\hline $\mathrm{C} / \mathrm{H}$ & $\delta \mathrm{H}^{\mathrm{a}}$ & $\delta \mathrm{C}$ \\
\hline 1 & - & 159.5 \\
2 & $6.41 \mathrm{br} \mathrm{s}$ & 101.0 \\
3 & - & 148.9 \\
4 & $6.38 \mathrm{br} \mathrm{s}$ & 104.0 \\
5 & - & 162.3 \\
6 & $6.24 \mathrm{br} \mathrm{s}$ & 106.6 \\
$1^{\prime}$ & $4.48 \mathrm{t}(7.1)$ & 75.2 \\
$2^{\prime}$ & $1.72 \mathrm{~m}$ & 36.30 \\
$3^{\prime}$ & $1.31 \mathrm{~m}$ & 36.33 \\
$4^{\prime}$ & $3.73 \mathrm{~m}$ & 68.5 \\
$5^{\prime}$ & $1.22 \mathrm{~d}(6.2)$ & 23.5 \\
6 & $3.73 \mathrm{~s}$ & 55.6 \\
\hline
\end{tabular}

${ }^{a}$ Coupling constants $(J$ in $\mathrm{Hz})$ are given in parentheses. 
confirmed these assignments. The ${ }^{13} \mathrm{C}$ NMR spectrum of 9 displayed then signals for twelve carbons, six of which could be attributed to the aromatic carbons, one to the OMe group and the five remaining to the aliphatic carbons of the aromatic ring side-chain (Table 2). The chemical shift values of $\delta 162.3$ and 159.5 were consistent with the presence of a methoxyl and a hydroxyl respectively, in a meta orientation with respect to each other in the 1,3,5trisubstituted aromatic ring, while the signal at $\delta 148.9$ was ascribed to the aromatic carbon bearing the alkyl chain. One of the methine carbons of this side-chain was shown to be directly attached to the aromatic ring on the basis of the correlations observed in the HMBC spectrum between its corresponding carbinol hydrogen $(\delta 4.48)$ and the aromatic carbons C-2, C-3 and C-4. Likewise, the location of the second hydroxyl group at C-4' was inferred by the appearance of the C-5' methyl as a doublet at $\delta 1.22$ $(J=6.2 \mathrm{~Hz})$, which in turn showed one-bond ${ }^{1} \mathrm{H}^{-13} \mathrm{C}$ connectivity with the carbon signal at $\delta 23.5$ (C-5') and by the long-range correlations of the carbinolic hydrogen H-4' with C-2', C-3' and C-5'. The structure of 9, which is being described for the first time in the literature, was thus established as 3-(1,4-dihydroxypentyl)-5-methoxyphenol.

Table 3. ${ }^{1} \mathrm{H}(300 \mathrm{MHz})$ and ${ }^{13} \mathrm{C}(75 \mathrm{MHz}) \mathrm{NMR}$ spectral data for 13a $\left(\delta, \mathrm{CDCl}_{3}\right)$

\begin{tabular}{ccc}
\hline $\mathrm{C} / \mathrm{H}$ & $\delta \mathrm{H}^{\mathrm{a}}$ & $\delta \mathrm{C}$ \\
\hline 1 & $2.04 \mathrm{~m}$ & 33.5 \\
2 & $5.35 \mathrm{~m}$ & 120.5 \\
3 & - & 134.4 \\
4 & & 31.3 \\
5 & $1.94 \mathrm{~m}$ & 30.6 \\
6 & & 39.6 \\
7 & - & 153.0 \\
8 & $2.13 \mathrm{~m}$ & 28.2 \\
8 & $2.04 \mathrm{~m}$ & 33.5 \\
9 & $2.26 \mathrm{~m}$ & 27.2 \\
10 & $6.71 \mathrm{~m}$ & 142.2 \\
11 & - & 127.5 \\
12 & - & 168.6 \\
13 & $1.70 \mathrm{~s}$ & 12.3 \\
14 & $4.70(\mathrm{br} \mathrm{s})$ & 107.7 \\
& $4.75(\mathrm{br} \mathrm{s})$ & \\
$\mathrm{OMe}$ & $1.55 \mathrm{~s}$ & 23.3 \\
\hline
\end{tabular}

A crude ethanol extract of the trunk bark of $O$. minarum was partitioned between methanol- $\mathrm{H}_{2} \mathrm{O}(9: 1)$ and hexane. Sesquiterpene 13 (Lanceolic acid) and $\beta$-sitosterol (14) were obtained from the hexane soluble fraction after column chromatography on silica gel. Compound 13 was isolated and characterized after methylation with diazomethane as its methyl ester derivative 13a. The ${ }^{1} \mathrm{H}$ NMR spectrum of 13a showed, in addition to a singlet at $\delta$
3.68 assignable to a carbomethoxy group, signals for two vinylic hydrogens (two multiplets at $\delta 5.35$ and 6.71), an exocyclic methylene group (two broad singlets at $\delta 4.70$ and 4.75) and two olefinic methyl groups at $\delta 1.55$ and 1.70 (Table 3). The ${ }^{13} \mathrm{C}$ NMR data (including DEPT) of 13a resembled closely those of the sesquiterpene $\beta$ bisabolene, ${ }^{5}$ except for the deshielding and shielding shifts of the $\mathrm{C}-10$ and $\mathrm{C}-11$ resonances, respectively, caused by the presence of a carbomethoxy function in 13a in place of the C-12 methyl group (Table 3). The stereochemical assignments for the 10,11-trisubstituted double bond in 13a were confirmed as $(\mathrm{E})$ on the basis of the proton and carbon resonances of methyl-13 $(\delta 1.70$ and 12.3, respectively), which were indicative of its cis relationship with C-9. ${ }^{6}$ Further evidence for the structure 13a was provided by two- and three-bond correlations discernible in the HMBC spectrum (Table 3). Since the optical rotation of 13a showed a negative value, the $(\mathrm{S})$ stereochemistry at C-6 is proposed, similarly to other analogous (S)-(E)bisabolene derivatives. ${ }^{7,8}$ Therefore, compound 13a was characterized as the methyl ester of lanceolic acid $\mathbf{1 3 .}$ These two compounds were previously obtained by synthesis and only incomplete ${ }^{1} \mathrm{H}$ NMR assignments have been published for 13a. ${ }^{7,9}$ Therefore, $\mathbf{1 3}$ is reported for the first time as a genuine natural product.

The structures of the known compounds 2 - 7, 10 - 12 and 14 were identified by comparison of their ${ }^{1} \mathrm{H}$ and ${ }^{13} \mathrm{C}$ NMR data with those found in the literature and/or with authentic samples. ${ }^{10}$

The isolation of $\mathbf{1}$ from Ocotea minarum is noteworthy for its chemosystematic relevance, since members of the Lauraceae have been reported to contain aporphine and benzyltetrahydroisoquinoline but not indole alkaloids. ${ }^{11}$ It is also worth of mention in this work the compartmentalized accumulation of the secondary metabolites present in $O$. minarum: the indole alkaloid and the flavonoid derivatives are accumulated in the fruits, whereas the alkyl phenols, the aryl propene derivative and the lignan were isolated from the heartwood and the sesquiterpene from the trunk bark.

\section{Experimental}

\section{General experimental procedures}

IR spectra were recorded as $\mathrm{KBr}$ pellets on a BomemHartmann \& Braun FT IR spectrometer. The unidimensional ${ }^{1} \mathrm{H}$ and ${ }^{13} \mathrm{C}$ and the two dimensional ${ }^{1} \mathrm{H}-{ }^{1} \mathrm{H}$ COSY, HMQC and HMBC NMR spectra were recorded at $300 \mathrm{MHz}\left({ }^{1} \mathrm{H}\right)$ and $75 \mathrm{MHz}\left({ }^{13} \mathrm{C}\right)$ on a Bruker DPX-300 spectrometer. Standard pulse sequences were used for 
homo- and heteronuclear correlation experiments. ESIMS spectra were obtained using a Micromass Platform II single quadrupole mass spectrometer (Faculdade de Ciências Farmacêuticas, USP, Ribeirão Preto, SP, Brazil). Optical rotations were determined on a Perkin-Elmer 341 polarimeter. Silica gel 60 (70-230 and 230-400 mesh) and Sephadex LH-20 were used for column chromatography. Reversed phase semi-preparative HPLC separations were performed with a Shimadzu LC-6AD pump, using a RP$18,25 \times 250 \mathrm{~mm}, 5 \mu \mathrm{m}$ particle size, Shim-Pack PREPODS(H) column, with a flow rate of $10 \mathrm{~mL} \mathrm{~min}^{-1}$ and monitoring at $254 \mathrm{~nm}$.

\section{Plant material}

Fruits, heartwood and trunk bark of Ocotea minarum (Meissn.) Mez. were collected in Campo Grande, Mato Grosso do Sul, Brazil, in December 2001. The plant material was identified by Dr. João Batista Baitello (Horto Florestal - São Paulo, SP, Brazil) and a voucher specimen (No. 11467) was deposited at the CGMS Herbarium, Universidade Federal de Mato Grosso do Sul, MS, Brazil.

\section{Extraction and isolation of chemical constituents}

Ground fruits $(2.5 \mathrm{~kg})$ were extracted at room temperature with $\mathrm{EtOH}$. The residue obtained from the EtOH extract was partitioned between hexane- $\mathrm{CH}_{3} \mathrm{CN}$ $\mathrm{CHCl}_{3}-\mathrm{H}_{2} \mathrm{O}$ (20:34:10:10) originating two phases: the organic upper layer and the hydro-organic lower layer. The first contained only fatty material which was not further investigated. The hydro-organic phase was concentrated in vacuo and the residue extracted with EtOAc and then with $n$-BuOH. The EtOAc extract (6.5 g) was subjected to $\mathrm{CC}$ on silica gel (230-400 mesh, $50 \mathrm{~g}$, $\mathrm{CHCl}_{3}-\mathrm{MeOH}$ gradient) to afford $2(3.8 \mathrm{mg})$ and $\mathbf{3}$ (16.9 $\mathrm{mg})$. The $n$-BuOH extract $(6.4 \mathrm{~g})$ was chromatographed on a Sephadex LH-20 column (30 g, four portions of $1.6 \mathrm{~g}$ each, $\mathrm{MeOH}$ ) to provide fifty fractions of $5 \mathrm{~mL}$ each. The fractions showing similar spots by TLC were combined to give eight fractions $(\mathrm{A} \rightarrow \mathrm{H})$. Fraction $\mathrm{E}$ was further subjected to $\mathrm{CC}$ on Sephadex LH-20 (30 g, MeOH) to yield fifty fractions of $5 \mathrm{~mL}$ each. From these, fractions 8 14 consisted of $\mathbf{1}$ ( $25.0 \mathrm{mg}$ ), fractions 19-27 yielded 6 (4.5 $\mathrm{mg})$ after semi-preparative $\mathrm{HPLC}\left(\mathrm{MeOH}-\mathrm{H}_{2} \mathrm{O}\right.$ 1:1), fractions $38-42$ afforded $4(9.8 \mathrm{mg})$ and fractions $47-49$ gave 5 (5.3 mg).

Air dried and powdered heartwood (900 g) was extracted at room temperature with EtOH. After concentration in vacuo, the residue $(29.0 \mathrm{~g})$ was applied to a silica gel CC (70-230 mesh, $100 \mathrm{~g}$, hexane-EtOAc and
EtOAc-MeOH gradients) to give nine fractions $(\mathrm{A} \rightarrow \mathrm{I})$ of $100 \mathrm{~mL}$ each. Fraction D (683 mg) afforded 10 (6.4 mg) and 11 (8.3 mg) after CC on silica gel (230-400 mesh, 50 $\mathrm{g}$, hexane-EtOAc 7:3), followed by a second CC (silica gel 230-400 mesh, $30 \mathrm{~g}, \mathrm{CHCl}_{3}-\mathrm{CH}_{2} \mathrm{Cl}_{2}$ 99.5:0.5). Fractions E-G (1.3 g) were subjected to CC on Sephadex LH 20 (50 $\left.\mathrm{g}, \mathrm{CHCl}_{3}-\mathrm{MeOH} 4: 1\right)$ to provide forty-two fractions of 10 $\mathrm{mL}$ each. Fractions 4-7 were rechromatographed on a silica gel column (230-400 mesh, $\left.50 \mathrm{~g}, \mathrm{CHCl}_{3}-\mathrm{MeOH} 1: 1\right)$ to yield 8 (7.3 mg) and 9 (5.3 mg). Fraction H (900 mg) was again separated by CC on Sephadex LH-20 (30 g, EtOAc$\mathrm{MeOH} \mathrm{1:1)} \mathrm{to} \mathrm{give} 7(11.5 \mathrm{mg})$ and $12(10.6 \mathrm{mg})$.

Air-dried and powdered trunk bark $(2.7 \mathrm{~kg})$ were extracted at room temperature with EtOH. After concentration in vacuo, the residue was partitioned between $\mathrm{MeOH}-\mathrm{H}_{2} \mathrm{O}$ 9:1 and hexane. The hexane phase (5.0 g) was separated on a silica gel column (230-400 mesh, $45 \mathrm{~g}$ ) eluted with a gradient of hexane-EtOAc 8:2 and hexane-EtOAc-MeOH 9:1:0.2, 8:2:1 and 7:3:1 yielding one hundred fractions of $10 \mathrm{~mL}$ each. Fraction 20 consisted of $14(465.0 \mathrm{mg})$. Fraction 8 (600 mg) consisted of a complex mixture from which 13 was isolated as the corresponding methyl ester derivative 13a (10 mg) after treatment of part of this fraction $(300 \mathrm{mg}$ ) with an ethereal solution of diazomethane followed by successive CC separations on silica gel (230-400 mesh, $50 \mathrm{~g}$, hexane-EtOAc gradient).

Tryptophol-5-O- $\beta$-D-glucopyranoside (1). Colorless amorphous solid. $[\alpha]$ : - 29.3 (MeOH; $c 0.3)$. IR (KBr) $v_{\max }$ ' $\mathrm{cm}^{-1}: 3400,2927,1628,1482,1202,1074,1041,803$. UV $\lambda_{\max } / \mathrm{nm}(\log \varepsilon)(\mathrm{MeOH}): 225$ (2.7), 280 (sh). ESIMS $\mathrm{m} / z$ $362[\mathrm{M}+\mathrm{Na}]^{+} .{ }^{1} \mathrm{H}$ and ${ }^{13} \mathrm{C}$ NMR: see Table 1 .

5-propylresorcinol (8). Brownish oil. ${ }^{1} \mathrm{H} \mathrm{NMR}\left(\mathrm{CDCl}_{3}\right)$ : $\delta 0.83$ (3H, t, J 6.6 Hz, H-3'), 1.50 ( 2H,m, H-2'), 2.39 ( $2 \mathrm{H}$, t, J7.5 Hz, H-1'), 5.86 (2H, br s, 2 x OH), $6.16(2 \mathrm{H}$, br s, H2, H-4), $6.28\left(1 \mathrm{H}\right.$, br s, H-2) ${ }^{13} \mathrm{C} \mathrm{NMR}\left(\mathrm{CDCl}_{3}\right): \delta 14.1(\mathrm{C}-$ 3'), 32.0 (C-2'), 36.0 (C-1'), 100.2 (C-4), 107.9 (C-2, 6), 146.1 (C-1), 156.7 (C-3, 5).

3-(1,4-dihydroxypentyl)-5-methoxyphenol (9). Colorless amorphous solid. [ $\alpha$ ]: - 10.0 $\left.0^{\circ} \mathrm{MeOH} ; c 0.17\right)$. IR (KBr) $v_{\max } / \mathrm{cm}^{-1}:$ 3401, 2926, 2854, 1598, 1456, 1437, 1337, 1301, 1154, 1054, 840, 699. ESIMS m/z 249 $[\mathrm{M}+\mathrm{Na}]^{+} .{ }^{1} \mathrm{H}$ and ${ }^{13} \mathrm{C}$ NMR: see Table 2.

Methyl lanceolate (13a). Colorless oil. [a]: - 58.0 $\left(\mathrm{MeOH} ; c\right.$ 0.25). IR (KBr) $v_{\max } / \mathrm{cm}^{-1}: 1720,1652,1135$, 891. ${ }^{1} \mathrm{H}$ and ${ }^{13} \mathrm{C}$ NMR: see Table 3. 


\section{Acknowledgments}

The authors are grateful to Fundect-MS, CPq-PROPPUFMS and PROAP-CAPES for their financial support and to CAPES and CNPq for the scholarships awards. Thanks are also due to Dr. Norberto P. Lopes (Faculdade de Ciências Farmacêuticas, USP, Ribeirão Preto, Brazil) for the ESIMS spectra.

\section{References}

1. Vecchietti, V.; Casagrande, C.; Ferrari, G.; Severini Ricca, G.; Farmaco-Ed. Sci. 1979, 34, 829.

2. Pouchert, C. J.; Behnke, J.; The Aldrich Library of ${ }^{13} \mathrm{C}$ and ${ }^{1} \mathrm{H}$ FT NMR Spectra, Aldrich Chemical Co.:Milwaukee, 1993, vol. 3.

3. Rayle, D. R.; Purves, W. K.; Plant Physiol. 1967, 42, 520; Erdogan, I.; Sener, B., Higa T.; Biochem. Syst. Ecol. 2000, 28, 793; Sugawara, F.; Strobel, G. A.; Phytochemistry 1987, 26, 1349.

4. Attygalle, A. B.; Siegel, B.; Vostrowsky, O.; Bestmann, H. J.; Maschwitz, U.; J. Chem. Ecol. 1989, 15, 317.

5. Rahman, A.; Ahmad, V. U.; ${ }^{13}$ C NMR of Natural Products Vol. 1, Monoterpenes and Sesquiterpenes, Plenum Press: New York, 1992.
6. Breitmaier, E.; Voelter, W.; ${ }^{13} C N M R$ Spectroscopy, $2^{\text {nd }}$ ed., Verlag Chemie: New York, 1978.

7. Manjarrez, A.; Ríos, T.; Guzmán, A.; Tetrahedron 1954, 20, 333.

8. Crawford, R. J.; Erman, W. F.; Broaddus, C. D.; J. Am. Chem. Soc. 1972, 94, 4298.

9. Katzenellenbogen, J. A.; Crumrine, A. L.; J. Am. Chem. Soc 1976, 98, 4925.

10. Agrawal, P. K.; Thakur, R. S.; Bansal, M. C. In Carbon-13 NMR of Flavonoids; Agrawal, P. K., ed.; Elsevier: Amsterdam, 1989, ch. 3; Agrawal, P. K.; Bansal, M. C. In Carbon-13 NMR of Flavonoids; Agrawal, P. K., ed.; Elsevier: Amsterdam, 1989, ch. 6; Agrawal, P. K.; Thakur, R. S.; Magn. Reson. Chem. 1985, 23, 389; González, M. C.; Sentandreu, M. A.; Rao, K. S.; Zafra-Polo, M. C.; Cortes, D.; Phytochemistry 1996, 43, 1361; Kojima, H.; Sato, N.; Hatano, A.; Ogura, H.; Phytochemistry 1990, 29, 235; Almeida, M. L. S.; Kocovský, P.; Bäckvall, J-E.; J. Org. Chem. 1996, 61, 6587.

11. Garcez, W. S.; Yoshida, M.; Gottlieb, O. R.; Phytochemistry 1995, 39, 815 .
Received: June 8, 2005 Published on the web: October 11, 2005 